\title{
Investigations into the utility of high-surface area silica pellets as potential solid-phase synthesis supports
}

\author{
Roxana S. Timofte, ${ }^{\mathrm{a}}$ Jeremy J. Titman, ${ }^{\mathrm{b}}$ Limin Shao, ${ }^{\mathrm{b}}$ John C. Stephens ${ }^{\mathrm{b}}$ \\ and Simon Woodward ${ }^{\mathrm{b}, *}$ \\ ${ }^{a}$ Faculty of Industrial Chemistry, 'Gh. Asachi’ Technical University, 6600 Iasi, Romania \\ ${ }^{\mathrm{b}}$ School of Chemistry, University Park, The University of Nottingham, Nottingham NG7 2RD, United Kingdom
}

Received 24 August 2004; revised 28 September 2004; accepted 21 October 2004

Available online 11 November 2004

\begin{abstract}
Grace-Davidson silica pellets (SMR-057-015) are found to be optimal for surface grafting of $(\mathrm{RO})_{3} \mathrm{Si}\left(\mathrm{CH}_{2}\right)_{3} \mathrm{FG}$ reagents. While loadings of up to $2.1 \mathrm{mmol} \mathrm{g}^{-1}$ can be attained (ca. $0.05 \mathrm{mmol}$ per pellet) access of further reagents to the graft sites is problematic above loadings of $0.8 \mathrm{mmol} \mathrm{g}{ }^{-1} \cdot{ }^{13} \mathrm{C}$ CPMAS NMR studies may be carried out on individual pellets (using natural abundance substrates) and the resulting spectra are diagnostic in identifying successful subsequent coupling reactions.
\end{abstract}

(C) 2004 Elsevier Ltd. All rights reserved.

\section{Introduction}

Combinatorial chemistry has heralded a near exponential growth in interest in applications of Solid-Phase Organic Synthesis (SPOS) in the last decade. ${ }^{1}$ While considerable innovation has been achieved, the majority of this chemistry is still carried out on organic supports, mainly cross-linked polystyrene (and related species). ${ }^{2}$ Approaches using alternative supports (especially silica and alumina, Fig. 1) have been investigated much less frequently, and often only in specialist areas. For example, silica powders serve as the basis for several commercial solid-phase scavenger reagents especially morpholine and related amines. ${ }^{3}$ Use of these and related reagents is well documented. ${ }^{4} \mathrm{~A}$ further significant number of reports deal with the attachment of metal complexes or organo-functions to silica surfaces to yield heterogeneous catalysts and sensors. ${ }^{5}$ Finally, a few publications detail actual multi-step syntheses carried out on silica, notably Sucholeiki's Claisen rearrangement chemistry. ${ }^{6}$ All of these investigations have used powdered supports. The powdered nature of such materials can make them difficult to handle, especially when drying under vacuum due to 'bumping'. Attempts have been made to overcome these problems through the use of glass beads, and related technologies, ${ }^{7}$ but these have the limitation that only low levels (in mmol $\mathrm{g}^{-1}$ ) of functionalisation have been attained. We believed that the alternative use of fused

\footnotetext{
Keywords: Supported reagents; Silica; Coupling reactions.

* Corresponding author. Tel.: +44 115951 3541; fax: +44 115951 3564; e-mail: simon.woodward@nottingham.ac.uk
}

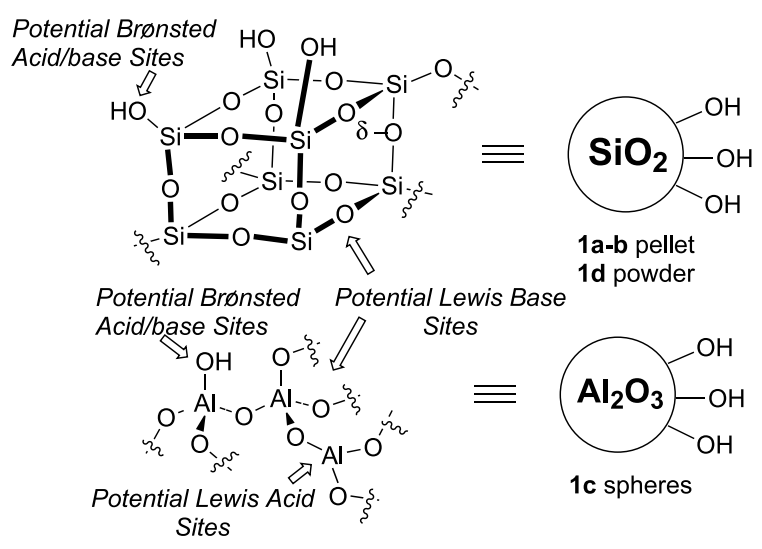

Figure 1. Schematic representation of silica and alumina surfaces.

silica and alumina pellets or spheres, commonly used to prepare heterogeneous catalysts through salt impregnation, might offer advantages in chemistry leading to supported synthesis of ligands and catalyst discovery. The lack of literature precedent led us to make a full investigation of the scope and limitations of such approaches using simple model systems and these are reported here.

Fused silica and alumina materials had not been used previously for supported reagents at the start of our studies. As their surfaces are not as innocent as those of polystyrene (and related) resins we were anxious to find out if the presence of residual Brønsted and Lewis acid/bases sites (Fig. 1) would affect the utility of these materials. 
Table 1. Functionalisation of various inorganic supports $\mathbf{1}^{\mathrm{a}}$

\begin{tabular}{ll}
\hline Inorganic support & Silane 2, Y group \\
\hline High surface area silica extrudate [Grace-Davidson: SMR-057-015] 1a & $\mathbf{2 a}, \mathrm{NH}_{2}$ \\
High surface area silica extrudate [Grace-Davidson: SMR-057-015] 1a & $\mathbf{2 c}, \mathrm{Cl}$ \\
Low surface area silica extrudate [Criterion Catalysts: KL7200CY] 1b & $\mathbf{2 a}, \mathrm{NH}_{2}$ \\
Low surface area silica extrudate [Criterion Catalysts: KL7200CY] 1b & $\mathbf{2 b}, \mathrm{NEt}_{2}$ \\
High surface area alumina spheres [Rhodia (Axens): SPH501a] 1c & $\mathbf{2 a}, \mathrm{NH}_{2}$ \\
High surface area alumina spheres [Rhodia (Axens): SPH501a] 1c & $\mathbf{2 c}, \mathrm{Cl}$ \\
Chromatographic silica powder [Fluorochem 35-70u, 60A) 1d & $\mathbf{2 a}, \mathrm{NH}_{2}$ \\
\hline
\end{tabular}

${ }^{\mathrm{a}}$ Reaction on $1.00 \mathrm{~g}$ of support with $22-93 \mathrm{mmol}$ of silane, $1.35-1.42 \mathrm{M}$ silane in toluene, reflux $3 \mathrm{~h}$.

${ }^{\mathrm{b}}$ Mass change per gram assumed due to gain of $\mathrm{Si}\left(\mathrm{CH}_{2}\right)_{3} \mathrm{Y}$ from $\mathbf{2}$ and loss of $3 \mathrm{H}$ from 1 normalized per gram of final product.

Additional questions to be answered were: (i) are sufficient reactive sites available to allow the synthetically useful loadings to be attained? (ii) would diffusion problems (of reagents into, or out of, the support) be encountered? and (iii) can the synthesis be monitored by standard diagnostic methods? Elements of our data have been the subject of a preliminary communication ${ }^{8}$ in an area in which other groups have also been attracted to recently.

\section{Functionalisation of inorganic supports}

To identify an optimal support, initial trials were made. Several different types of silica extrudate $\mathbf{1 a}-\mathbf{b}$ and alumina spheres 1c were obtained from commercial suppliers [Criterion Catalysts, Grace-Davidson and Rhodia (Axens) all via Johnson-Matthey Ltd] and these were screened for grafting ability by reaction with $(\mathrm{RO})_{3} \mathrm{Si}\left(\mathrm{CH}_{2}\right)_{3} \mathrm{Y}$ reagents $\left(\mathrm{R}=\mathrm{Et}, \mathrm{Y}=\mathrm{NH}_{2} \mathbf{2 a}, \mathrm{NEt}_{2} \mathbf{2 b} ; \mathrm{R}=\mathrm{Me}, \mathrm{Y}=\mathrm{Cl}, \mathbf{2 c}\right)$ under standard conditions (reflux in toluene in the presence of excess silane ${ }^{8}$ ). A chromatographic grade silica powder 1d was also reacted, under identical conditions, to allow direct comparison with known approaches. In all cases, derived loadings were calculated gravimetrically assuming the weight gain per gram of support was due to the attachment of $\mathrm{Si}\left(\mathrm{CH}_{2}\right)_{3} \mathrm{Y}$ group and loss of $3 \mathrm{H}$ (Table 1).

The superiority of the Grace-Davidson high surface area silica extrudate SMR-057-015 (pellets approximately $6 \mathrm{~mm}$ long by $4 \mathrm{~mm}$ in diameter) was very clear from these preliminary runs. Low surface area extrudate performed worse than a typical silica powder while alumina spheres were only a little better. Both the latter support types were also rather fragile and easily damaged by mechanical stirring during functionalisation. Investigations on the optimal SMR-057-015 pellets revealed that the degree of grafting was essentially independent of the amount $(\mathrm{EtO})_{3^{-}}$ $\mathrm{Si}\left(\mathrm{CH}_{2}\right)_{2} \mathrm{NH}_{2}$ 2a used at ratios above $20 \mathrm{mmol} \mathrm{2a} / \mathrm{g}$ of pellets used. Commonly, before reaction with silanes, silica powders are activated by either heating or treatment with acids prior to heating..$^{10}$ In our case, heating (ca. $130{ }^{\circ} \mathrm{C}$, $0.5 \mathrm{mmHg}, 16-24 \mathrm{~h})$ SMR-057-015 had little effect on the loading realised. However, $6 \mathrm{M} \mathrm{HCl}_{\mathrm{aq} \text {. }}$ acid treatment increased the apparent loading up to 2.15 provided excess 2a and long reaction times were employed. ${ }^{8}$ Even when low amounts of 2a $\left(1.2 \mathrm{mmol} \mathrm{g}^{-1}\right)$ were used, significant loadings of the Grace-Davidson pellets could be realised $\left(\sim 0.6 \mathrm{mmol} \mathrm{g}^{-1}\right.$, see Section 7$)$. The Grace-Davidson SMR-057-015 material is reported as having a total pore volume of $1.39 \mathrm{~mL} \mathrm{~g}^{-1}$ with a distribution (based on mercury intrusion studies) favoring macropores in the
10-20 nm diameter range. ${ }^{11}$ Because of the apparent superiority of this material in the initial grafting studies, further characterisation by BET (Brunauer-Emmett-Teller) isotherms were carried out both on the initial 1a and with the pellets (3a) attained after treatment with $(\mathrm{EtO})_{3} \mathrm{Si}\left(\mathrm{CH}_{2}\right)_{3^{-}}$ $\mathrm{NH}_{2}$ 2a. Typical data are compared in Table 2.

Table 2. Surface area and pore distribution data

\begin{tabular}{lll}
\hline Technique & $\begin{array}{c}\text { Pellet 1a } \\
\text { (prior to grafting) }\end{array}$ & $\begin{array}{c}\text { Pellet 3a } \\
\text { (grafted) }\end{array}$ \\
\hline BET surface area $/ \mathrm{m}^{2} \mathrm{~g}^{-1}$ & 295 & 220 \\
Langmuir surface $\mathrm{area} / \mathrm{m}^{2} \mathrm{~g}^{-1}$ & 280 & 181 \\
BJH pore distribution $/ \mathrm{mL} \mathrm{g}^{-1}(\%)$ & \\
Under $10 \mathrm{~nm}$ & $0.11(9 \%)$ & $0.10(12 \%)$ \\
$10-20 \mathrm{~nm}$ & $0.22(18 \%)$ & $0.18(22 \%)$ \\
$20-80 \mathrm{~nm}$ & $0.88(70 \%)$ & $0.48(58 \%)$ \\
Over $80 \mathrm{~nm}$ & $0.04(3 \%)$ & $0.07(8 \%)$ \\
Total pore volume $/ \mathrm{mL} \mathrm{g}^{-1}$ & 1.25 & 0.83 \\
$\mathrm{Hg}$ intrusion pore distribution $/ \mathrm{mL} \mathrm{g} \mathrm{g}^{-1}(\%):$ & $\mathrm{c}$ \\
$10-25 \mathrm{~nm}$ & $1.00(72 \%)$ & \\
$25-50 \mathrm{~nm}$ & $0.38(27 \%)$ & \\
$50-150 \mathrm{~nm}$ & $0.10(1 \%)$ & \\
Total pore volume $/ \mathrm{mL} \mathrm{g}^{-1}$ & 1.39 & \\
\end{tabular}

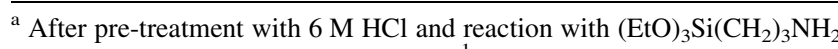
2a; gravimetric loading $2.15 \mathrm{mmol} \mathrm{g}^{-1}$.

${ }^{\mathrm{b}}$ Literature data (Ref. 11).

${ }^{\mathrm{c}}$ Data not available. $\mathrm{BJH}=$ Barret-Joyner-Halenda isotherm.

Unfunctionalised pellets 1a typically displayed a BET surface area of ca. $295 \mathrm{~m}^{2} \mathrm{~g}^{-1}$ but occasional batches with lower surface areas (down to $245 \mathrm{~m}^{2} \mathrm{~g}^{-1}$ ) were encountered. Clearly mesopores predominate in $\mathbf{1 a}$ with the majority being $20-80 \mathrm{~nm}$ in diameter. These pores are of appropriate dimensions to accommodate $\mathrm{Si}\left(\mathrm{CH}_{2}\right)_{3} \mathrm{NH}_{2}$ fragments whose molecular dimensions are of the order of $0.47 \times 0.31 \mathrm{~nm}$ (based on molecular modeling studies ${ }^{12}$ ). Comparison of the $\mathrm{BJH}$ pore distribution data for $\mathbf{1 a}$ and $\mathbf{3 a}$ indicates: firstly, that it is the $20-80 \mathrm{~nm}$ pores that are the most functionalised (the distribution shifts to lower pore volumes upon reaction); and secondly, that $\mathrm{HCl}$ activation may operate by increasing the number of macropores (diameter above ca. $100 \mathrm{~nm}$ ) in these pellet materials. Depending on the quality of the pellets 1a used in the preparation of $\mathbf{3 a}$ the pore distribution could be degraded. For example, when reduced surface area pellets (1a, $245 \mathrm{~m}^{2} \mathrm{~g}^{-1}$ ) were used, the fraction of $20-80 \mathrm{~nm}$ pores fell to $40 \%$ while those in the range up to $20 \mathrm{~nm}$ rose to $57 \%$. Acid treated samples showed a slight rise (1-2\%) in the number of large pores $(>80 \mathrm{~nm})$. Acid-treated pellets and samples with higher distributions of smaller pore sizes were found to be less effective in subsequent coupling reactions (see later). 
To test the generality of the apparent ease of silane binding to $1 \mathrm{a}$ a range of derivatives was prepared by reaction with commercially available silanes $(\mathrm{RO})_{3} \mathrm{Si}\left(\mathrm{CH}_{2}\right)_{3} \mathrm{Y}$ and in one case $(\mathrm{MeO})_{2} \mathrm{Si}(\mathrm{Me})\left(\mathrm{CH}_{2}\right)_{3} \mathrm{NH}_{2}$ in refluxing toluene. Specific conditions for the couplings have already been reported in a preliminary communication, ${ }^{8}$ so only the gravimetrically derived final loadings are given in Scheme 1. Typically, these functionalised materials displayed BET surface areas in the range $175-280 \mathrm{~m}^{2} \mathrm{~g}^{-1}$ regardless of the anchor function in $\mathbf{3}$ (e.g. 3e 225; 3 g 174; 3 h 242; 175-280 range over all pellets screened $\left.\mathrm{m}^{2} \mathrm{~g}^{-1}\right)$.

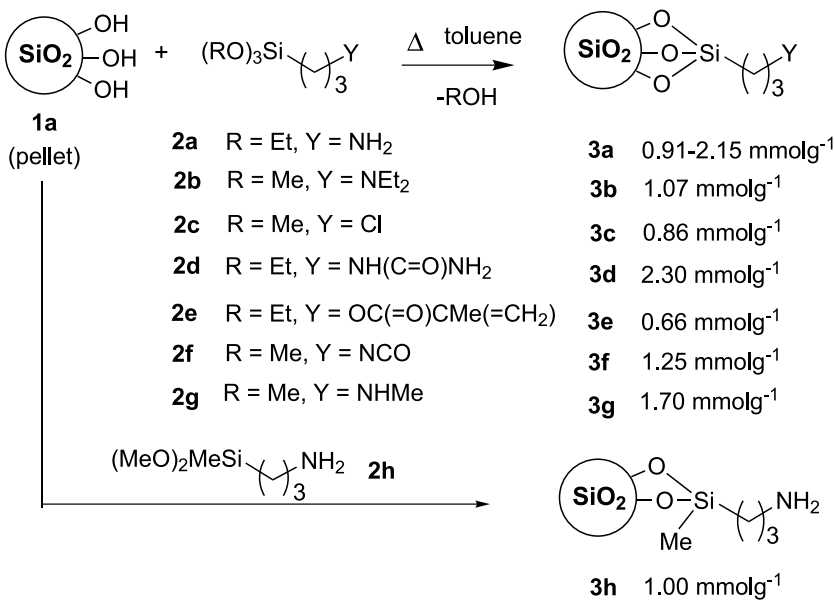

Scheme 1. Silane grafted pellet materials based on SMR-057-015.

\section{Pellet loading and characterisation studies}

The loadings attained in the silane grafting studies (Scheme 1) are considerably higher that have been attained with many other non-powder inorganic supports. For example, glass beads have been used in combinatorial studies but here loadings of $\sim 0.1 \mathrm{mmol} \mathrm{g}^{-1}$ are typical. ${ }^{7}$ Because the data in Scheme 2 were determined gravimetrically there was a worry that the apparent high loadings may be in fact just due to physisorbed materials (unreacted starting materials, solvents or byproducts) and have little to do with the actual formation of $\mathbf{3}$. To confirm the loadings of 3a derived from weight gain studies we sought a simple titration approach through protonation of the amine function and back titration of the remaining free acid with $\mathrm{NaOH}$. As silica is susceptible to dissolution under alkali conditions we selected bromocresol purple ( $\mathrm{pH}$ change at 5.2-6.8) as a suitable indicator. Pelleted 3a titrated thus gave amine loadings consistently 10-15\% lower than those derived gravimetrically. We suspected that these reduced values were indicative of reduced accessibility of amines present in

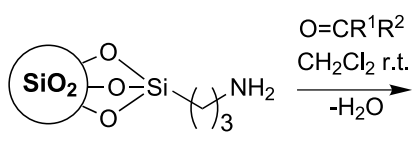

$3 \mathbf{a}$

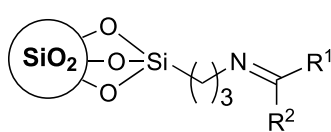

$\mathrm{R}^{2}$

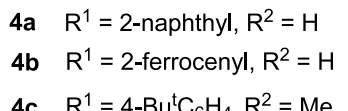

4c $\mathrm{R}^{1}=4-\mathrm{Bu}^{\mathrm{t}} \mathrm{C}_{6} \mathrm{H}_{4}, \mathrm{R}^{2}=\mathrm{Me}$
Scheme 2. Imine formation studies on amino pellets $\mathbf{2 a}$. the smaller and more inaccessible pores. Grinding 3a to a powder prior to assay increased the measured loading to the gravimetric value consistent with this idea. In these cases the ground silica had to be removed by filtration prior to titration to avoid erroneous results through alkali silica dissolution. The extent of pellet loading in 3a (0.63-2.15) could be also be controlled by limiting the number of equivalents of $\mathbf{2 a}$ (1.2 to 40 equiv) used in the preparation.

To confirm that the weight gains in the pellets 1a after reaction with $(\mathrm{RO})_{3} \mathrm{Si}\left(\mathrm{CH}_{3}\right)_{2} \mathrm{Y} 2$ reagents were not due to simple physio adsorption of $\mathrm{ROH}$ by-products or toluene solvent TGA-MA (thermogravimetric analysis-mass analysis) studies were carried out on $\mathbf{3 a}$ and 3c. Pellets were heated from ambient temperature to $960{ }^{\circ} \mathrm{C}$ (at $10{ }^{\circ} \mathrm{C} \mathrm{min}^{-1}$ ) and the off-gas composition monitored by mass spectrometry in the range $m / z$ 2-97 amu. Pellet 3a $\left(\mathrm{R}=\mathrm{OEt} ; \mathrm{Y}=\mathrm{NH}_{2}\right)$ lost $2 \%$ of its initial weight below around $100{ }^{\circ} \mathrm{C}$ and a further $7 \%$ by the end of heating. No evidence of appreciable toluene or ethanol production was present in the MS data. Most material was cleaved in the region $490-560{ }^{\circ} \mathrm{C}$. Pellet $3 \mathrm{c}(\mathrm{R}=\mathrm{OMe} ; \mathrm{Y}=\mathrm{Cl})$ lost $7 \%$ of its weight on heating, the majority being lost at $350-500{ }^{\circ} \mathrm{C}$. No evidence of thermal expulsion of methanol or toluene was observed. Tentative assignments for the major fragment losses are given in Figure 2. Control experiments in which pellets 1a were placed in toluene or alcohols and then dried led to no weight gains or losses.

\begin{tabular}{|c|c|c|c|c|}
\hline \multirow[b]{2}{*}{ Temp $/{ }^{\circ} \mathrm{C}$} & \multicolumn{2}{|c|}{ From 3a } & \multicolumn{2}{|c|}{ From 3c } \\
\hline & $m / z$ & Fragment & $m / z$ & Fragment \\
\hline up to 500 & & & $50 / 52$ & $\mathrm{Me}^{35 / 37} \mathrm{Cl}$ \\
\hline 500 & 16 & $\mathrm{MeH}$ & & \\
\hline 550 & $\begin{array}{l}26 \\
42\end{array}$ & $\begin{array}{c}\mathrm{HC} \equiv \mathrm{CH} \\
+{ }^{+} \mathrm{CH}_{2} \mathrm{CH}=\mathrm{NH}\end{array}$ & & \\
\hline $\begin{array}{l}600 \\
650\end{array}$ & $\begin{array}{l}42 \\
56\end{array}$ & $+\left(\mathrm{CH}_{2}\right)_{3} \mathrm{NH}_{2}$ & $\mid \begin{array}{c}26 \\
64 / 66\end{array}$ & $\begin{array}{l}\mathrm{HC} \equiv \mathrm{CH} \\
\mathrm{MeCH}_{2}{ }^{35 / 37} \mathrm{Cl}\end{array}$ \\
\hline
\end{tabular}

Figure 2. Major fragments detected in TGA-MA analysis of pellets $\mathbf{3 a}$ and 3c.

Further confirmation that materials $\mathbf{3}$ have been correctly formulated is supplied by ${ }^{13} \mathrm{C}$ cross polarisation magic angle spinning (CPMAS) NMR spectroscopy. The data collected from the pellets in this study are summarised in Table 3. Appreciable background signals are always present in the spectra of polystyrene supported reagents, due to the resin itself. ${ }^{13}$ However, only one very broad residual signal was encountered in the carbon spectra of 3 at $\delta_{\mathrm{C}} \sim 175$. We believe this to be due to the residue from the organic formerly used in the sol-gel process to prepare 1a. The presence of only this minimal background allowed ${ }^{13} \mathrm{C}$ data to be attained in $5-20 \mathrm{~h}$ on single pellets. In general aliphatic carbons gave sharp, well resolved, signals. A typical example is given in Figure 3. Poorer dispersion was obtained for the aromatic carbons due in part to spinning sidebands observed as expected at multiples of $53.0 \mathrm{ppm}$ away from the isotropic peak at the MAS rate of $4 \mathrm{kHz}$ used. ${ }^{14}$ In some of our samples intrinsically weak signals 
Table 3. Carbon-13 CPMAS NMR data (75.47 MHz, MAS rate $4 \mathrm{kHz})$ of various pellets 3-11

\begin{tabular}{|c|c|c|c|c|}
\hline Pellet & $\delta \mathrm{SiCH}_{2}$ & $\delta \mathrm{CH}_{2}$ cen. & $\delta \mathrm{YCH}_{2}$ & $\delta$ Other Signals \\
\hline $\mathbf{3 a}$ & 9.5 & 27.0 & 44.2 & $16.7,58.0(\mathrm{OEt})^{\mathrm{a}}$ \\
\hline $\mathbf{3 b}$ & $11.2^{\mathrm{b}}$ & 21.8 & $47.2^{\mathrm{b}}$ & $54.1,56.9(\mathrm{OEt})^{\mathrm{a}}$ \\
\hline 3c & 8.7 & 25.9 & 45.9 & - \\
\hline 3d & 10.3 & 24.0 & 43.0 & $161.4(\mathrm{C}=\mathrm{O})$ \\
\hline $3 \mathbf{e}$ & 16.3 & 21.6 & 49.1 & $6.5(\mathrm{Me}), 124.1,137.2(\mathrm{C}=\mathrm{C}), 168.4(\mathrm{C}=\mathrm{O})^{\mathrm{c}}$ \\
\hline 3f & 8.2 & 22.8 & 42.4 & $16.6,58.2(\mathrm{OEt})^{\mathrm{d}}, 160.3(\mathrm{C}=\mathrm{O})$ \\
\hline $3 \mathbf{g}$ & 10.1 & 23.0 & 34.4 & $54.9(\mathrm{NMe})$ \\
\hline $3 \mathbf{h}$ & 13.5 & 26.7 & 44.6 & $-3.2(\mathrm{SiMe})$ \\
\hline $4 \mathbf{a}$ & 10.9 & 20.0 & 24.8 & $127.7,133.8(\mathrm{Ar})^{\mathrm{e}}, 186.8(\mathrm{C}=\mathrm{NR})$ \\
\hline $4 b$ & $\underline{\mathrm{f}}^{\mathrm{f}}$ & - & - & $69.4 \mathrm{br}(\mathrm{Cp})$ \\
\hline $4 c$ & 9.7 & 22.8 & 40.9 & $9.7\left(\mathrm{Bu}^{\mathrm{t}}\right), 124.8,124.9(\mathrm{Ar})^{\mathrm{e}}, 174.5(\mathrm{C}=\mathrm{N}) ; 16.756 .6(\mathrm{OEt})^{\mathrm{g}}$ \\
\hline 5 & 10.3 & 20.0 & 38.9 & $32.5\left(\mathrm{CH}_{2} \mathrm{CO}\right), 53.2 \mathrm{sh}\left(\mathrm{CH}_{2} \mathrm{O}\right), 174.4(\mathrm{C}=\mathrm{O})^{\mathrm{h}}$ \\
\hline 6 & 9.4 & 23.4 & $-{ }^{\mathrm{i}}$ & $33.6,43.7,53.8(\mathrm{NMe})$ \\
\hline 8 & 9.2 & $21.0,24.8^{\mathrm{j}}$ & $35.7,42.3^{\mathrm{j}}$ & $116.4,124.9,127.8,143.5\left(\mathrm{Ar}^{\mathrm{e}}\right), 162.0^{\mathrm{j}}, 169.3^{\mathrm{j}}(\mathrm{C}=\mathrm{O})$ \\
\hline 9 & 8.1 & $21.9 \mathrm{br}$ & $44.3 \mathrm{br}$ & $115.5,125.9,128.5,158.1,\left(\mathrm{Ar}^{\mathrm{e}}\right), 161.8^{\mathrm{j}}, 167.9^{\mathrm{j}}, 169.9^{\mathrm{j}}(\mathrm{C}=\mathrm{O})$ \\
\hline 11c & 10.4 & 23.1 & 46.5 & $126.1 \mathrm{br}\left(\mathrm{Ar}^{\mathrm{e}}\right), 179.4(\mathrm{C}=\mathrm{S})^{\mathrm{e}}$ \\
\hline 11d & 9.9 & 19.7 & 34.4 & $53.5(\mathrm{NMe}), 126.4$ br $\left(\mathrm{Ar}^{\mathrm{e}}\right), 174.5(\mathrm{C}=\mathrm{S})^{\mathrm{e}}$ \\
\hline
\end{tabular}

${ }^{\text {a }}$ Due to residual SiOEt, only observed at partial conversion to $\mathbf{3}$.

${ }^{\text {b }}$ SilylCH $\mathrm{H}_{2}$ overlapped by $\mathrm{MeCH} \mathrm{CH}_{2} \mathrm{~N} \mathrm{YCH}_{2}$ signal overlapped by $\mathrm{N}\left(\mathrm{CH}_{2} \mathrm{Me}\right)_{2}$.

c A signal at 66.1 could not be assigned.

d Major product at extended reaction is $\mathrm{Y}=\mathrm{NHCO}_{2} \mathrm{Et}$.

e The major aromatic signals (and carbonyls were indicated) show strong sidebands at $\pm 53.0 \mathrm{ppm}$.

${ }^{\mathrm{f}}$ The $\left(\mathrm{CH}_{2}\right)_{3}$ tether showed only a broad signal at $21 \mathrm{ppm}$, imine signal not observed.

Impurity derived from $\mathrm{HC}(\mathrm{OEt})_{3}$.

${ }^{\mathrm{h}}$ A signal at 17.1 could not be assigned.

i Overlapped by NMe signal.

${ }^{\mathrm{j}}$ Ascribed to surface conformers or partial conversion (see text).

$(\mathrm{C}=\mathrm{O}, \mathrm{C}=\mathrm{S}$, and $\mathrm{C}=\mathrm{N})$ could not be detected within acceptable accumulation times $(5-20 \mathrm{~h})$.

The spectra confirmed the formation of single silica bound

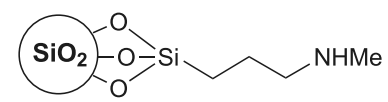

$3 \mathrm{~g}$

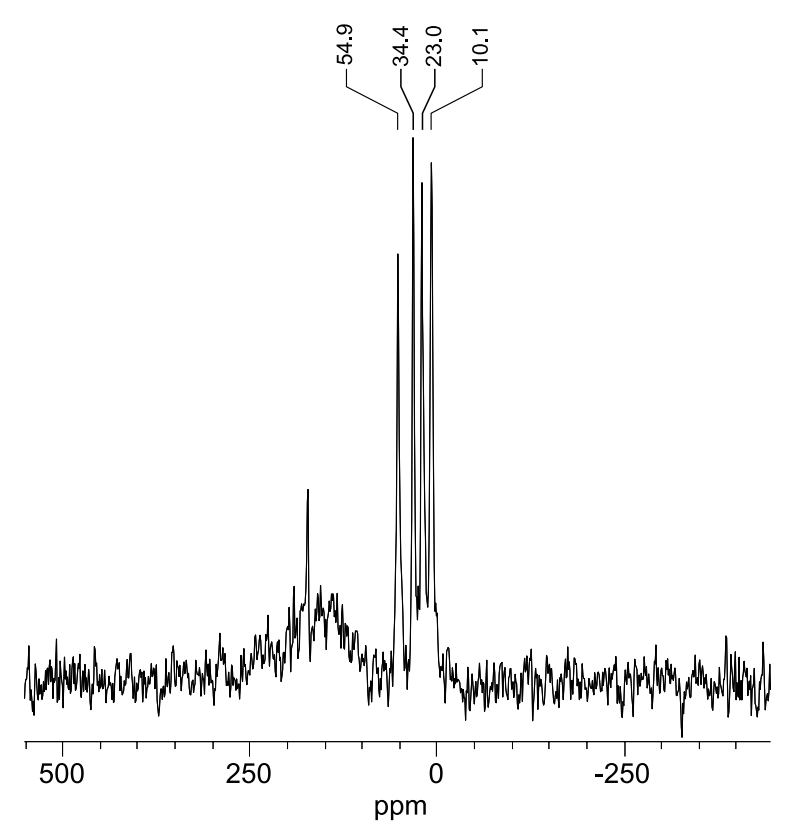

Figure 3. Typical solid-state ${ }^{13} \mathrm{C}$ CPMAS NMR spectra (75.47 MHz, MAS rate $4 \mathrm{kHz})$ of functionalised pellet $\mathbf{3 g}(\mathrm{Y}=\mathrm{NHMe})$. The sharp spike and associated very broad resonance at ca. $175 \mathrm{ppm}$ are inate features of the silica pellets $\mathbf{1 a}$ as supplied. entities for the most of the materials screened. For 3a occasional samples showed two extra peaks at 16.7 and $58.0 \mathrm{ppm}$ which disappeared on extended reaction or storage of the pellets. These are assigned to residual SiOEt in partially reacted 2a. Similar features were encountered in the spectra of $\mathbf{3 b}$ although in this case two residual $\mathrm{OCH}_{2}$ signal were apparent. Nominal $\mathbf{3 f}(\mathrm{Y}=\mathrm{NCO})$ showed extra signals at 16.6 and $58.2 \mathrm{ppm}$ revealing that long reaction times lead to smooth conversion to the alcoholysis product of $\mathbf{2 f}$, i.e. $\mathrm{Si}\left(\mathrm{CH}_{2}\right)_{3} \mathrm{NHCO}_{2} \mathrm{Et}$.

\section{Coupling studies}

As no organic syntheses on pelleted silica materials had been reported initial coupling studies concentrated on simple imine formation (Scheme 2). Representative results are given in Table 4. In general, the coupling efficiencies of 3a having apparently high amine loadings $\left(>1.0 \mathrm{mmol} \mathrm{g}^{-1}\right)$ were not good even when large excesses of aldehyde were used (compare runs 1 and 2 leading to $\mathbf{4 a}$ ). This situation was made worse if the pellets leading to $\mathbf{3 a}$ had been acid pre-treated. Loadings of $0.6-0.8 \mathrm{mmol} \mathrm{g}^{-1} \mathrm{NH}_{2}$ led to the best, but not quantitative, yields. We speculate that 2a having the highest loadings $\left(>1.0 \mathrm{mmol} \mathrm{g}^{-1}\right)$ has a significant fraction of its amine groups in small pores that are not available for reaction through blocking of the pellet capillaries through over functionalisation with $(\mathrm{EtO})_{3^{-}}$ $\mathrm{Si}\left(\mathrm{CH}_{2}\right) \mathrm{NH}_{2}$ 2a. The ${ }^{13} \mathrm{C}$ CPMAS NMR spectra of poorly coupled 4a are identical to those of high coupling efficiency indicating that formation of alternative products is not the cause of the poor performance. Acid pre-treatment also appears to promote small capillary blocking as very poor coupling efficiencies were always noted in reactions of $\mathbf{2 a}$ prepared from acid-washed pellets. Ferrocene derivative $\mathbf{4 b}$ was used to probe this idea. The ${ }^{13} \mathrm{C}$ CPMAS NMR spectra 
Table 4. Imine preparations using pellet $\mathbf{2} \mathbf{a}^{\mathrm{a}}$

\begin{tabular}{|c|c|c|c|}
\hline 2a Loading/mmol g ${ }^{-1}$ & Conditions & 4 Loading $^{\mathrm{b}} / \mathrm{mmol} \mathrm{g}^{-1}$ & Eff. $/ \%$ \\
\hline $1.48^{\mathrm{c}}$ & 12.5 equiv $\mathrm{C}_{10} \mathrm{H}_{8} \mathrm{CHO}, 0.9 \mathrm{M}, 28 \mathrm{~h}, \mathrm{rt}$ & $4 \mathbf{a} 0.63$ & 42 \\
\hline 0.63 & 3.1 equiv $\mathrm{C}_{10} \mathrm{H}_{8} \mathrm{CHO}, 0.1 \mathrm{M}, 4 \mathrm{~h}, \mathrm{rt}$ & 4a 0.57 & 90 \\
\hline 0.63 & 3.1 equiv $\mathrm{C}_{10} \mathrm{H}_{8} \mathrm{CHO}, 0.1 \mathrm{M}, 1 \mathrm{~h}, \mathrm{rt}$ & 4a 0.50 & 79 \\
\hline 1.05 & 3.1 equiv $\mathrm{C}_{10} \mathrm{H}_{8} \mathrm{CHO}, 0.07 \mathrm{M}, 2 \mathrm{~h}, \mathrm{rt}$ & 4a 0.47 & 45 \\
\hline 1.05 & 0.63 equiv $\mathrm{C}_{10} \mathrm{H}_{8} \mathrm{CHO}, 0.1 \mathrm{M}, 1 \mathrm{~h}, \mathrm{rt}$ & $4 \mathbf{a} 0.25$ & 38 \\
\hline $2.02^{\mathrm{c}}$ & 3.2 equiv $\mathrm{FcCHO}, 0.15 \mathrm{M}, 16 \mathrm{~h}, \mathrm{rt}$ & 4b 0.45 & 22 \\
\hline 0.63 & 3.2 equiv $\mathrm{FcCHO}, 0.02 \mathrm{M}, 16 \mathrm{~h}, \mathrm{rt}$ & 4b 0.56 & 89 \\
\hline 1.35 & 0.64 equiv $4-\mathrm{Bu}^{\mathrm{t}} \mathrm{C}_{6} \mathrm{H}_{4} \mathrm{C}(\mathrm{O}) \mathrm{Me}$ and $\mathrm{HC}(\mathrm{OEt})_{3}, 0.08 \mathrm{M}, 1 \mathrm{~h}, \mathrm{rt}$ & $4 b 1.08^{\mathrm{d}}$ & $\sim 60^{\mathrm{d}}$ \\
\hline
\end{tabular}

${ }^{\text {a }}$ In dry dichloromethane under argon.

${ }^{\mathrm{b}}$ Loading based on weight gain. Eff. is coupling efficiency equivalent to chemical yield.

${ }^{\mathrm{c}}$ Prepared from acid pre-treated 1a.

${ }^{\mathrm{d}}$ Contains orthoformate derived by-product, see text. Coupling yield based on NMR ratios.

of derived $\mathbf{4 b}$ was uninformative, being rather broad, but it did confirm the presence of $\mathrm{Cp}$-derived units. (There are suggestions that supported ferrocenes give inferior spectra from the limited polystyrene literature available. ${ }^{15}$ ). To probe if acid induced modification of the pellets does take place at the pellet surface, or throughout the sample, a pellet of $\mathbf{4 b}$ (derived from acid treated 1a) was cleaved across its diameter and subjected to EDX-backscatter techniques under electron microscopy. The pellet was imaged in $250 \times 180 \mu \mathrm{m}$ segments across its diameter. Functionalised silane linkers were detected at an equivalent $\% \mathrm{Fe}$ density throughout the pellet indicating that homogeneous solutions do penetrate the core of the pellet. Within each segment small clusters (within $10^{2} \mu \mathrm{m}$ ) of high iron concentration could be found in addition to an essentially random single Fe background sites across the segment. We interpret these as indicative of clusters of $\mathbf{4 b}$ at pore defects that may block access to smaller capillaries and pores reducing coupling efficiency.

Support for these ideas comes from reactions of $\mathbf{4 a}$ (ex $\mathbf{3 a}$, $1.05 \mathrm{mmol} \mathrm{g}^{-1}$ ) with a second addition of 2-naphthaldehyde. Poor coupling yields are still realised as might be expected if some pores are inaccessible even under mild conditions. Formation of $\mathbf{4 c}$ required the addition of a dehydrating agent $\left[\mathrm{HC}(\mathrm{OEt})_{3}\right]$ and the loading attained exceeds that expected from the reaction stoichiometry based on the weight of pellet $\mathbf{4 c}$ recovered. However, the ${ }^{13} \mathrm{C}$ CPMAS NMR spectrum of this material shows ca. $40 \%$ of 3a remains. The expected signals for $\mathbf{4 c}$ are present except for the acyl methyl and $\mathrm{CMe}_{3}$ resonance. In the starting ketone these signals resonate at 31.2 and $35.2 \mathrm{ppm}$ and it is possible that they are coincident with the broad $\mathrm{CH}_{2} \mathrm{~N}$ imine signal observed at $\delta_{\mathrm{C}}$ 40.9. Additionally, an OEt derived signal is present at 16.7 and $56.6 \mathrm{ppm}$. This is assigned to chemisorbed orthoformate (or derived products) on the basis that no other ethyl source is present in the preparation and it could not be removed even on extensive drying under high vacuum.

Propiolactone acylated 3a with excellent coupling efficiency (Scheme 3) yielding amide 5. Similarly, methyl iodide alkylations were highly effective to leading to salt $\mathbf{6}$ (83-96\% coupling yield) based on gravimetric yield. However, additional signals were present in the ${ }^{13} \mathrm{C}$ CPMAS NMR spectra of pellet 6 . Use of ${ }^{13} \mathrm{C}$-enriched MeI confirmed the presence of three ammonium methyl signals. The origin of this effect is unclear but it seems likely that adsorption of the polar head group onto more than one site on the silica surface is the likely explanation. The possibility of $\mathbf{3} \mathbf{g}$ formation (through HI loss) can be eliminated as this compound has been independently prepared and its $\delta_{\mathrm{C}}(\mathrm{NMe})$ shift $54.9 \mathrm{ppm}$ is not present in the spectra of $\mathbf{6}$.

Acylation of 3a with $\mathrm{PhOC}(\mathrm{O}) \mathrm{Cl} / \mathrm{NEt}_{3}$ was far less effective. Initial, gravimetrically determined yields of $\mathbf{7}$ appeared high but were masked by the the fact that the $\mathrm{NHEt}_{3} \mathrm{Cl}$ by-product is strongly absorbed onto the silica and this could only be removed by washing the pellets in $90{ }^{\circ} \mathrm{C}$ water. The final purified 7 was only attained with coupling efficiencies of 19-29\% no matter what conditions were employed. Acceptable ${ }^{13} \mathrm{C}$ CPMAS NMR spectra of 7 were not obtained. To confirm the presence of the carbamate on 7 $\mathrm{PhOH}$ was cleaved from the support, in a subsequent step, by TFA and could be isolated by preparative TLC. We speculated that the low yields in the formation of $\mathbf{7}$ are due to blockage of the pellet capillaries by strongly adsorbed ammonium salt co-products. Cleavage of a single pellet of $\mathbf{7}$ after initial acylation and inspection under UV light
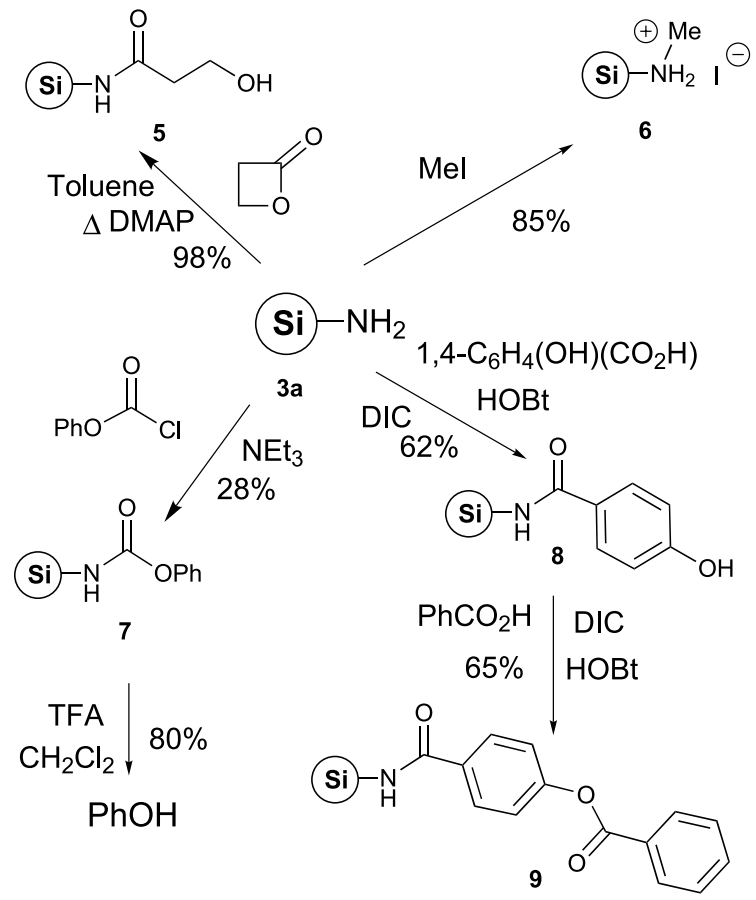

Scheme 3. Further solid-phase reactivity studies on $\mathbf{3 a}$. 
suggested reaction mainly at the pellet surface. This behaviour appears general and could be visualised easily in reactions with other coloured charged reagents. For example, reaction of $\mathbf{3 a}$ or $\mathbf{3} \mathbf{g}$ with the diazonium salt [1,4$\left.\operatorname{Br}\left(\mathrm{N}_{2}\right) \mathrm{C}_{6} \mathrm{H}_{4}\right] \mathrm{BF}_{4}$, which is yellow in colour, led (under Bräse's conditions ${ }^{16}$ ) only to a thin surface coating to the pellets.

In an attempt to overcome these problems amide formation from 3a was attempted under Lee's conditions using DIC and HOBt in NMP (Scheme 3). ${ }^{6 a}$ Reaction with 1,4hydroxybenzoic acid under these conditions led to some improvement in coupling efficiencies yielding up to 57$66 \%$ of nominal 8 based on weight gain. The ${ }^{13} \mathrm{C}$ CPMAS NMR spectrum of pelleted $\mathbf{8}$ revealed a doubling up of the $\mathrm{CH}_{2} \mathrm{~N}$ and carbonyl signals. We tentatively assign this as due to the partial conversion, but the possibility of different surface conformers cannot be excluded. Attempts to further functionalise 8 by reaction with $\mathrm{PhOC}(\mathrm{O}) \mathrm{Cl} /$ pyridine couplings were ineffective due to the same difficulties observed in the formation of 7. Again the conditions of $\mathrm{Lee}^{6 \mathrm{a}}$ provided a partial solution to this problem. While the majority of $\mathbf{8}$ was converted into a new material, assigned structure 9 , on the basis of ${ }^{13} \mathrm{C}$ CPMAS NMR spectroscopy. However, three carbonyl signal are present in these spectra. Again this may be due to the presence of surface conformers or partial conversion. We attempted to exclude the possibility of by-product formation but support cleavage reactions were unsuccessful. It was concluded that synthetic sequences on the pellets should be kept short and free of polar by-products.

\section{Supported ligand preparation}

Due to the problems encountered in reactions of $\mathbf{3 a}$ with salt producing electrophiles, thiocarbonate $\left(S_{a}\right)$-10 was selected as potentially the most effective route to silica-bound thiocarbamate ligands 11 (Scheme 4). Such species have shown some utility in copper-catalysed asymmetric additions of organozinc and organic aluminum reagents to enones. ${ }^{17}$ Compound $\left(S_{a}\right)$-10 was prepared by reaction of $\left(S_{a}\right)$-BINOL under conditions analogous to those used to prepare its biphenol analogue. ${ }^{18}$ Solution ${ }^{13} \mathrm{C}$ NMR spectroscopy confirmed the symmetrical $\mathrm{O}-\mathrm{C}(\mathrm{S})-\mathrm{O}$ unit was present a conclusion reinforced by the presence of a strong $\nu(\mathrm{C}=\mathrm{S})$ stretch at $1262 \mathrm{~cm}^{-1}$. This reaction is somewhat capricious, and on occasions an uncharacterised $\mathrm{C}_{1}$ binaphthyl product was formed, apparently a dimer of $\left(S_{a}\right)$-10. To confirm that $\left(S_{a}\right)$-10 would open cleanly with amines, and without appreciable racemisation, to the desired thiocarbamates at the silica surface, the compound was treated with diethyl amine or pyrrolidine at room temperature as models for the surface reaction. In both cases, chiral HPLC confirmed that no appreciable racemisation took place during thiocarbamate opening. When 3a or $\mathbf{3} \mathbf{g}$ were reacted with excess $\left(S_{a}\right)$-10 the coupling efficiencies, based on net mass gain are very encouraging $(>90 \%)$. However, extensive washing with dichloromethane led to much lower final yields $(31-44 \%)$.

Our initial claim of efficient coupling for this reaction is therefore in error. ${ }^{8}$ As highly loaded sources of $\mathbf{3}$

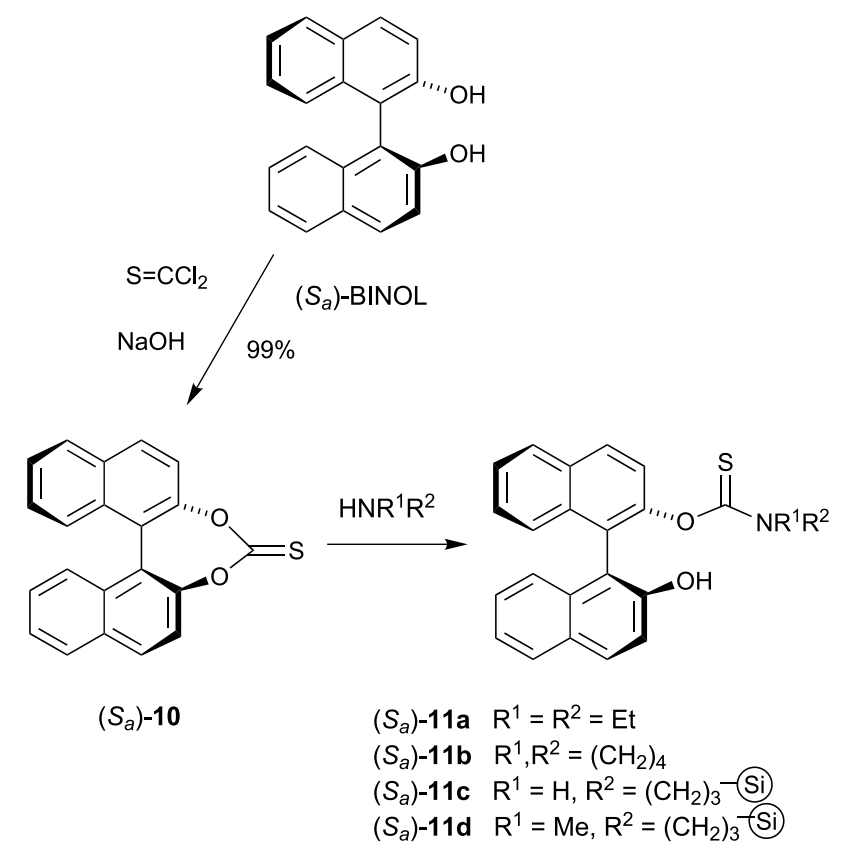

Scheme 4. Preparation of silica supported thioamide ligands.

$\left(1.7 \mathrm{mmol} \mathrm{g}^{-1}\right.$ amine) were used for these studies it is likely that the reduced reactivity arises from the capillary blocking/accessibility problems in the pellet. Trials of these pellets in asymmetric conjugate addition studies have already been reported. ${ }^{8}$ While ${ }^{13} \mathrm{C}$ CPMAS NMR studies confirmed the attachment of the binaphthyl fragment, broad spectra were encountered limiting the assignments that could be made.

\section{Discussion and conclusions}

It has been discovered that, in common with all supports, pelleted silica materials have both advantages and problems for use as solid-phase synthesis. They are of low cost and readily functionalised with a range of trialkoxysilane reagents. The ability to monitor the extent of reaction on single silica pellets by ${ }^{13} \mathrm{C}$ CPMAS NMR has been attained for the first time and this has proved extremely valuable in quantifying the purity of solid-phase bound materials (a very common problem in this area). The spectra are attained on natural abundance samples (within 5-20 h) and normally show sharp well resolved signals for aliphatic signals. Typically, poorer dispersion is attained for tethered aromatic species.

Grafting of the (RO) $)_{3} \mathrm{Si}\left(\mathrm{CH}_{2}\right)_{\mathrm{n}} \mathrm{Y}$ linkers to the pellets can be attained in a range $0.6-2.1 \mathrm{mmol} \mathrm{g}^{-1}$. Prior activation of the pellets (through heating or acid treatment) was not found to be beneficial. The mesoporous and capillary nature of the pellets causes a significant fraction of the graft sites to be unavailable for further reaction once loadings over ca. $1.0 \mathrm{mmol} \mathrm{g}{ }^{-1}$ are attained. The coupling efficiencies fall off dramatically in this case and complete functionalisation cannot be guaranteed even if excess reagents are used. This problem can be partially overcome if pellets with loadings of $0.6-0.8 \mathrm{mmol} \mathrm{g}^{-1}$ are used and no more than three synthetic reaction sequences using "click' ${ }^{19}$ reactions are 
attempted. Couplings that generate polar by-products, or precipitates, are best avoided as these lead to surface adsorption and pore clogging preventing subsequent synthesis.

\section{Experimental}

\subsection{General}

General synthetic instrumentation has been described previously. ${ }^{17 \mathrm{a}, \mathrm{b}}$ Carbon-13 CPMAS NMR measurements were carried out on a Varian InfinityPlus spectrometer at a Larmour frequency of $75.47 \mathrm{MHz}$ using a $7.5 \mathrm{~mm}$ double resonance MAS probe. Up to 9000 scans were recorded and CW proton decoupling at a field strength of $70 \mathrm{kHz}$ was applied during acquisition. Other parameters were as follows: MAS rate $4 \mathrm{kHz}$, relaxation delay $8 \mathrm{~s}$, contact time $1.7 \mathrm{~ms}$, spectral width $75 \mathrm{kHz}$. The TGA-MS studies were carried out on Perkin Elmer Pyris 1 Thermogravimetric analyser. A ramp rate of $10{ }^{\circ} \mathrm{C} \mathrm{min}-1$ was used to heat each sample from ambient to $900{ }^{\circ} \mathrm{C}$ in a nitrogen gas stream of $35 \mathrm{~mL} \mathrm{~min}^{-1}$. BET surface area studies were conducted on a Coulter SA 3200 Surface Area and Pore Size Analyzer. Electron microscopy studies were made on a FEI XL30 ESEM-FEG equipped with a EDAX DX4 system. Silica powder was chromatographic grade (Fluorochem 35-70u, 60A; 70-230 mesh powder). Silica extrudate were Criterion Catalysts (KL7200CY) and GraceDavidson (SMR-057-015) products. Alumina spheres were from Rhodia (now Axens) product SPH501a. All inorganic supports were gifts from Johnson-Matthey but are commercially available. Moisture sensitive reactions were conducted under an argon atmosphere. Toluene was HPLC grade, further distillation from sodium did not improve reaction efficiencies. Dichloromethane was distilled from $\mathrm{CaH}_{2}$. Other reagents were commercial products.

\subsection{Representative approach to functionalisation of inorganic supports}

A sample of $1.00 \mathrm{~g}$ of support $\left(\mathrm{SiO}_{2}\right.$ or $\mathrm{Al}_{2} \mathrm{O}_{3}$ extrudate/ spheres or silica powder $\mathbf{1 a - d}$ ) was suspended in toluene $(20.0 \mathrm{~mL})$ and $(\mathrm{EtO})_{3} \mathrm{Si}\left(\mathrm{CH}_{2}\right)_{3} \mathrm{NH}_{2}$ 2a $(10.0 \mathrm{~mL}, 9.46 \mathrm{~g}$, $42.6 \mathrm{mmol}$ ) added. The mixture was stirred and heated to reflux under argon $(3 \mathrm{~h})$. The reaction was cooled and the functionalised support filtered off and subjected to Soxlet extraction with toluene or dichloromethane (2-6 h). For toluene extractions the final support was washed with dichloromethane $(5 \times 10 \mathrm{~mL})$. The samples were dried under vacuum $\left(0.5 \mathrm{mmHg}, 100^{\circ} \mathrm{C}\right.$, typically $\left.16 \mathrm{~h}\right)$ to constant weight. Yield $1.122 \mathrm{~g}$ equiv to $1.22 \mathrm{mmol} \mathrm{g}^{-1}$. Occasionally, silica samples of $\mathbf{1 a}$ were activated by drying $\left(0.5 \mathrm{mmHg}, 110-140^{\circ} \mathrm{C}, 2-16 \mathrm{~h}\right)$ or by treatment with aqueous $6 \mathrm{M} \mathrm{HCl}$ (30 min.) followed by filtration, washing with copious distilled water, until the filtrate was $\mathrm{pH} 6.5$ to 7.0 , and final drying $\left(0.5 \mathrm{mmHg}, 120-140{ }^{\circ} \mathrm{C}, 24-48 \mathrm{~h}\right)$ to constant weight. Different loadings of 3a,c could be achieved by changing the $\mathbf{1 a : 2}$ ratio and conditions (Table 5). Analogous compounds $\mathbf{3 b}-\mathbf{3} \mathbf{g}$ were prepared by identical procedures using trialkoxysilane concentrations and excesses already reported. ${ }^{8}$

\subsection{Preparation of amide 5}

Five pellets of $\mathbf{3 a}\left(256.3 \mathrm{mg}\right.$, loading $1.06 \mathrm{mmol} \mathrm{g}^{-1}$, $0.27 \mathrm{mmol} \mathrm{NH}_{2}$ ) were suspended in toluene $(5 \mathrm{~mL})$. Betapropiolactone $(13 \mu \mathrm{L}, 18 \mathrm{mg}, 0.25 \mathrm{mmol})$ and DMAP ( $4.5 \mathrm{mg}, 0.05 \mathrm{mmol}$ ) were added. The reaction was refluxed under an inert atmosphere $(18 \mathrm{~h})$, the pellets filtered off, washed with dichloromethane $(5 \times 5 \mathrm{~mL})$ and dried under vacuum $\left(0.5 \mathrm{mmHg}, 100{ }^{\circ} \mathrm{C}\right)$ to constant weight. Yield 5 $272.3 \mathrm{mg}$ (indicating $1.05 \mathrm{mmol} \mathrm{g}^{-1}, 98 \%$ ). Spectroscopic data for the compound is reported in Table 3.

\subsection{Preparation of ammonium salt 6}

Five pellets of $3 \mathbf{a}\left(248.1 \mathrm{mg}\right.$, loading $1.06 \mathrm{mmol} \mathrm{g}^{-1}$, $0.26 \mathrm{mmol} \mathrm{NH}_{2}$ ) were suspended in dichloromethane (3 mL). Neat MeI ( $21 \mu \mathrm{L}, 47 \mathrm{mg}, 0.33 \mathrm{mmol})$. The reaction was refluxed under an inert atmosphere $(1 \mathrm{~h})$, the pellets filtered off, washed with dichloromethane $(5 \times 5 \mathrm{~mL})$ and dried under vacuum $\left(0.5 \mathrm{mmHg}, 100{ }^{\circ} \mathrm{C}\right)$ to constant weight. Yield $6261.1 \mathrm{mg}$ (indicating $1.02 \mathrm{mmol} \mathrm{g}^{-1}$, $91 \%$ ) Spectroscopic data for the compound is reported in Table 3 .

\subsection{Preparation of carbamate 7}

Five pellets of $\mathbf{2 a}\left(250.0 \mathrm{mg}\right.$, loading $0.66 \mathrm{mmol} \mathrm{g}^{-1}$, $0.17 \mathrm{mmol} \mathrm{NH}_{2}$ ) suspended in dichloromethane $(5 \mathrm{~mL})$ were treated with $\mathrm{PhOC}(=\mathrm{O}) \mathrm{Cl}(25 \mathrm{mg}, 0.18 \mathrm{mmol})$ and $\mathrm{NEt}_{3}(47 \mu \mathrm{L}, 0.34 \mathrm{mmol})$ and occasionally DMAP (1 mg, $5 \mathrm{~mol} \%$ ). The reaction was stirred for $1-2 \mathrm{~h}$, the pellets filtered off, washed with dichloromethane $(5 \times 5 \mathrm{~mL})$ and dried under vacuum. The weight of the pellets $(291.3 \mathrm{mg})$ suggested strong co-binding of the $\mathrm{NHEt}_{3} \mathrm{Cl}$ by-product. The pellets were suspended in hot water $\left(90^{\circ} \mathrm{C}, \mathrm{pH} 7\right.$, $30 \mathrm{~min})$, filtered off, washed with hot water $(3 \times 10 \mathrm{~mL})$, dichloromethane $(5 \times 5 \mathrm{~mL})$ and dried under vacuum

Table 5. Loadings of pellets $\mathbf{3 a}$ and $\mathbf{3 c}$ attained by varying conditions

\begin{tabular}{|c|c|c|}
\hline $2\left(\mathrm{mmol} \mathrm{g}^{-1}\right.$ pellets, conc./M) & Conditions & Loading $^{\mathrm{a}} \mathbf{3} / \mathrm{mmol} \mathrm{g}^{-1}$ \\
\hline $\mathbf{2 a}(1.2,1.42)$ & Undried pellets, ${ }^{\mathrm{b}}$ toluene $110^{\circ} \mathrm{C}, 2 \mathrm{~h}, \mathrm{CH}_{2} \mathrm{Cl}_{2}$ Soxlet $2 \mathrm{~h}$ & 0.63 \\
\hline $\mathbf{2 a}(2.6,0.32)$ & Undried pellets, ${ }^{\mathrm{b}}$ toluene $65^{\circ} \mathrm{C}, 2 \mathrm{~h}, \mathrm{CH}_{2} \mathrm{Cl}_{2}$ Soxlet $2 \mathrm{~h}$ & 0.94 \\
\hline $2 \mathbf{a}(2.7,0.32)$ & Dried pellets, ${ }^{\mathrm{c}}$ toluene $110^{\circ} \mathrm{C}, 2 \mathrm{~h}$, toluene Soxlet $2 \mathrm{~h}$ & 1.46 \\
\hline $\mathbf{2 a}(41,1.42)$ & Activated pellets, ${ }^{\mathrm{d}}$ toluene $110^{\circ} \mathrm{C}, 65 \mathrm{~h}$, toluene Soxlet $72 \mathrm{~h}$ & 2.01 \\
\hline $2 \mathbf{c}(2.2,0.68)$ & Undried pellets, ${ }^{\mathrm{b}}$ toluene $110^{\circ} \mathrm{C}, 1 \mathrm{~h}$, toluene Soxlet $16 \mathrm{~h}$ & 0.66 \\
\hline
\end{tabular}

${ }^{a}$ Mass change per gram assumed due to effective gain of $\mathrm{Si}\left(\mathrm{CH}_{2}\right)_{3} \mathrm{Y}$ from $\mathbf{2}$ and loss of $3 \mathrm{H}$ from $\mathbf{1}$ normalised per gram of final product.

${ }^{b}$ Pellets [Grace-Davidson: SMR-057-015] used as supplied.

${ }^{\mathrm{c}}$ Heated $110^{\circ} \mathrm{C}, 0.5 \mathrm{mmHg}, 16 \mathrm{~h}$.

${ }^{\mathrm{d}} \mathrm{HCl}$ treatment: $6 \mathrm{M}, 0.5 \mathrm{~h}$ followed by washing with distilled water until neutrality and drying $\left(140{ }^{\circ} \mathrm{C}, 0.5 \mathrm{mmHg}, 63 \mathrm{~h}\right)$. 
$\left(0.5 \mathrm{mmHg}, 100{ }^{\circ} \mathrm{C}\right)$ to constant weight. Yield $7256.1 \mathrm{mg}$ (indicating $0.20 \mathrm{mmol} \mathrm{g}^{-1}$ ).

Cleavage of pellets 7 (256.1 mg, loading $0.20 \mathrm{mmol} \mathrm{g}^{-1}$, $0.05 \mathrm{mmol}$ bound carbamate) with 1:3 TFA-dichloromethane $(1 \mathrm{~mL})$ led to formation of phenol within $30 \mathrm{~min}$ at room temperature by TLC (the pellet was ground up and destroyed in the reaction). Preparative TLC (4:1 Hexane/ $\mathrm{Et}_{2} \mathrm{O}$ ) led to the recovery of phenol $4.2 \mathrm{mg}(89) \%$.

\subsection{Preparation of amides 8 and 9}

Five pellets of 3a $\left(312.3 \mathrm{mg}\right.$, loading $1.277 \mathrm{mmol} \mathrm{g}^{-1}$, $0.40 \mathrm{mmol} \mathrm{NH}_{2}$ ) were suspended in $\mathrm{N}$-methylpyrrolidinone $(6 \mathrm{~mL})$. Solid $1,4-\mathrm{HOC}_{6} \mathrm{H}_{4} \mathrm{CO}_{2} \mathrm{H}(0.32 \mathrm{~g}, 2.32 \mathrm{mmol})$, HOBt $(0.42 \mathrm{~g}, 3.10 \mathrm{mmol})$ and 1,3-diisopropylcarbodiimide [DIC] $(0.47 \mathrm{~g}, 3.75 \mathrm{mmol})$ was added. The reaction was stirred under an inert atmosphere $(16 \mathrm{~h})$, the pellets filtered off, and washed extensively with DMF, dichloromethane, $\mathrm{MeOH}$ and $10 \% \mathrm{w} / \mathrm{w}$ piperidine in THF. The pellets were subjected to soxlet extraction with dioxane $(2 \mathrm{~h})$, final washing with dichloromethane and dried under vacuum $\left(0.5 \mathrm{mmHg}, 100{ }^{\circ} \mathrm{C}\right)$ to constant weight. Yield $8342.0 \mathrm{mg}$ (indicating $0.79 \mathrm{mmol} \mathrm{g}^{-1}, 62 \%$ ) Spectroscopic data for the compound is reported in Table 3. Attempted coupling of $\mathbf{8}$ with $\mathrm{PhOC}(\mathrm{O}) \mathrm{Cl} / \mathrm{pyridine}$ in dichloromethane led only to poor coupling uptakes (up to $28 \%$ yield of 9 ) under a variety of conditions.

The coupling of $\mathbf{8}$ to $\mathbf{9}$ was completed more successfully in an analogous manner from $8\left(342.0 \mathrm{mg}, 0.79 \mathrm{mmol} \mathrm{g}^{-1}\right.$, $0.27 \mathrm{mmol} \mathrm{OH}$ ), benzoic acid ( $255 \mathrm{mg}, 2.09 \mathrm{mmol}), \mathrm{HOBt}$ (283 mg, $2.09 \mathrm{mmol})$ and DIC (317 mg, $2.53 \mathrm{mmol})$. Yield $9360.4 \mathrm{mg}$ (indicating, $0.51 \mathrm{mmol} \mathrm{g}^{-1}, 65 \%$ coupling efficiency). Spectroscopic data for the compound is reported in Table 3.

\subsection{1,1'-Bis(2-naphthol)thiocarbonate $\left(S_{a}\right)-10$}

Thiophosgene $(0.4 \mathrm{~g}, 3.5 \mathrm{mmol})$ and a solution of $\mathrm{NaOH}$ $(0.28 \mathrm{~g}, 7.0 \mathrm{mmol}$ in $40 \mathrm{~mL}$ water) were added to a solution of $\left(S_{a}\right)$-BINOL $(1.0 \mathrm{~g}, 3.5 \mathrm{mmol})$ in dichloromethane $(140 \mathrm{~mL})$ containing $\mathrm{NBu}_{4} \mathrm{Br} \quad(0.11 \mathrm{~g}, \quad 0.35 \mathrm{mmol}$, $10 \mathrm{~mol} \%$ ). The reaction was stirred vigorously overnight. The organic phase was separated, dried $\left(\mathrm{Na}_{2} \mathrm{SO}_{4}\right)$ and the solution evaporated to pale brown fluffy solid. Recrystallisation from dichloromethane/hexane (1:1) yielded analytically pure pale rose coloured microcrystals $1.13 \mathrm{~g}$ (99\%). Prolonged storage or attempted chromatography led to decomposition. Mp 200-202 ${ }^{\circ} \mathrm{C} ;[\alpha]_{\mathrm{D}}+172(c=0.10$ $\left.\mathrm{CH}_{2} \mathrm{Cl}_{2}, 29^{\circ} \mathrm{C}\right)$; $\mathrm{IR}\left(\mathrm{KBr}\right.$ disc): $\nu_{\max } 2924 \mathrm{w}, 2353 \mathrm{w}$, $1461 \mathrm{w}, 1275 \mathrm{~m}, 1260 \mathrm{~m}(\mathrm{C}=\mathrm{S}), 1182 \mathrm{w}, 1122 \mathrm{w}, 764 \mathrm{~s}$, $750 \mathrm{~s} \mathrm{~cm}^{-1} ;{ }^{1} \mathrm{H}$ NMR $\left(\mathrm{CDCl}_{3}, 500.1 \mathrm{MHz}\right): \delta_{\mathrm{H}} 7.36-7.42$ $\left(2 \mathrm{H}, \mathrm{m}, \mathrm{H}_{8}\right), 7.50-7.57\left(4 \mathrm{H}, \mathrm{m}, \mathrm{H}_{6,7}\right), 7.60(2 \mathrm{H}, \mathrm{d}, J=$ $\left.8.9 \mathrm{~Hz}, \mathrm{H}_{3}\right), 7.98\left(2 \mathrm{H}, \mathrm{d}, J=7.9 \mathrm{~Hz}, \mathrm{H}_{5}\right), 8.04(2 \mathrm{H}, \mathrm{d}, J=$ $\left.8.9 \mathrm{~Hz}, \mathrm{H}_{4}\right) ;{ }^{13} \mathrm{C} \mathrm{NMR}\left(\mathrm{CDCl}_{3}, 126.0 \mathrm{MHz}\right): \delta_{\mathrm{C}} 119.5$, 122.4, 126.5, 127.0, 127.3, 128.7, 131.4, 131.5, 132.5, 152, $194.5(\mathrm{C}=\mathrm{S})$. Found: $\mathrm{C}, 76.83 ; \mathrm{H}$, 3.66. $\mathrm{C}_{21} \mathrm{H}_{12} \mathrm{O}_{2} \mathrm{~S}$ requires: $\mathrm{C}, 76.40 ; \mathrm{H}, 3.70 . \mathrm{m} / \mathrm{z}(\mathrm{EI}): 328\left(\mathrm{M}^{+}, 44 \%\right)$, 286(32), 269 (21), 268 (100), 239 (91), 120(22); [Found (HRMS, EI): $\mathrm{M}^{+}$328.0550. $\mathrm{C}_{21} \mathrm{H}_{12} \mathrm{O}_{2} \mathrm{~S}$ requires: $M$ 328.0558.].

\section{8. $\left(S_{a}\right)$-2-( $N, N$-Diethylthiocarbamoyloxy)-2' -hydroxy- 1,1'-binaphthyl $\left(S_{a}\right)$-11a}

Neat diethylamine $(51.7 \mu \mathrm{L}, 73.1 \mathrm{mg}, 1.00 \mathrm{mmol})$ was added to a solution of thiocarbonate $\left(S_{a}\right)-\mathbf{1 0}(0.33 \mathrm{~g}, 1.00$, $\mathrm{mmol})$ in dichloromethane $(6 \mathrm{~mL})$. The reaction completed at room temperature within $2 \mathrm{~h}$ (TLC, hexane/dichloromethane 2:1). The presence (up to 1.2 equiv) of DMAP did not appreciably reduce the conversion time. The solution was filtered through a plug of silica gel, evaporated, and the solid recrystallised from EtOH giving colourless microcrystals $0.36 \mathrm{~g}(89 \%)$. Mp132-133 ${ }^{\circ} \mathrm{C} ;[\alpha]_{\mathrm{D}}=-462(c=$ $\left.0.1, \mathrm{CCl}_{4}, 28^{\circ} \mathrm{C}\right)$; $\mathrm{IR}\left(\mathrm{KBr}\right.$ disc): $\nu_{\max } 3438 \mathrm{vs} ; 2358 \mathrm{w}$; $1646 \mathrm{~m} ; 1518 \mathrm{w} ; 1458 \mathrm{w} ; 1272 \mathrm{~m} ; 1260 \mathrm{~m}(\mathrm{C}=\mathrm{S}) ; 1210 \mathrm{w}$; $818 \mathrm{w} ; 764 \mathrm{~s} ; 750 \mathrm{~s} \mathrm{~cm}^{-1}$; ${ }^{1} \mathrm{H}$ NMR $\left(\mathrm{CDCl}_{3}, 500.1 \mathrm{MHz}\right)$ : $\delta_{\mathrm{H}} 0.46(3 \mathrm{H}, \mathrm{t}, J=7.2 \mathrm{~Hz}, \mathrm{Me}) ; 1.06(3 \mathrm{H}, \mathrm{t}, J=7.1 \mathrm{~Hz}, \mathrm{Me}) ;$ 2.82-2.89 (1H, m, $\left.\mathrm{CH}_{2} \mathrm{Me}\right) ; 3.13-3.2\left(1 \mathrm{H}, \mathrm{m}, \mathrm{CH}_{2} \mathrm{Me}\right)$; 3.57-3.68 (2H, m, $\left.\mathrm{CH}_{2} \mathrm{Me}\right) ; 5.93(1 \mathrm{H}, \mathrm{s}, \mathrm{OH}) ; 7.08(1 \mathrm{H}, \mathrm{d}$, $\left.J=8.4 \mathrm{~Hz}, \mathrm{H}_{8,8^{\prime}}\right) ; 7.21\left(1 \mathrm{H}, \mathrm{d}, J=7.1 \mathrm{~Hz}, \mathrm{H}_{8,8^{\prime}}\right) ; 7.23-7.28$ $\left(3 \mathrm{H}, \mathrm{m}, \mathrm{H}_{6,6^{\prime}}\right.$ or $\left.7,7^{\prime}\right) ; 7.31\left(1 \mathrm{H}, \mathrm{d}, J=8.8 \mathrm{~Hz}, \mathrm{H}_{3,3^{\prime}}\right) ; 7.41(1 \mathrm{H}$, $\left.\mathrm{d}, J=8.8 \mathrm{~Hz}, \mathrm{H}_{3,3^{\prime}}\right) ; 7.48\left(1 \mathrm{H}, \mathrm{m}, \mathrm{H}_{6,6^{\prime}}\right.$ or $\left.7,7^{\prime}\right) ; 7.80(1 \mathrm{H}, \mathrm{d}$, $\left.J=8.1 \mathrm{~Hz}, \mathrm{H}_{5,5^{\prime}}\right) ; 7.85\left(1 \mathrm{H}, \mathrm{d}, J=8.1 \mathrm{~Hz}, \mathrm{H}_{4,4^{\prime}}\right) ; 7.95(1 \mathrm{H}$, $\left.\mathrm{d}, J=8.2 \mathrm{~Hz}, \mathrm{H}_{5,5^{\prime}}\right) ; 8.04\left(1 \mathrm{H}, \mathrm{d}, J=8.2 \mathrm{~Hz}, \mathrm{H}_{4,4^{\prime}}\right) ;{ }^{13} \mathrm{C}$ NMR $\left(\mathrm{CDCl}_{3}, 126.0 \mathrm{MHz}\right): \delta_{\mathrm{C}} 11.6 ; 12.2 ; 43.9 ; 48.1 ; 115.1$; $119.5 ; 123.2 ; 123.5 ; 124.2 ; 124.7 ; 125.9 ; 126.3 ; 126.6$; $127.3 ; 128.0 ; 128.4 ; 129.2 ; 130.0 ; 130.15 ; 132.2 ; 133.7$; $133.9 ; 151.32 ; 152.3 ; 186.4(\mathrm{C}=\mathrm{S})$. Found: $\mathrm{C}, 74.81 ; \mathrm{H}$, 5.70; N, 3.34. $\mathrm{C}_{25} \mathrm{H}_{23} \mathrm{O}_{2} \mathrm{SN}$ requires: $\mathrm{C}, 74.72 ; \mathrm{H}, 5.72 ; \mathrm{N}$, 3.49. $\mathrm{m} / \mathrm{z}$ (EI): $401\left(\mathrm{M}^{+}, 54 \%\right), 286(57), 268(22), 239$ (30), 116 (48), 88 (31), 58 (35) 72 (100). [Found (HRMS, EI): $\mathrm{M}^{+}$401.1433. $\mathrm{C}_{25} \mathrm{H}_{23} \mathrm{O}_{2} \mathrm{SN}$ requires: $M$ 401.1450.].

HPLC (Daicel AD, hexane/isopropanol 97:3, flow rate

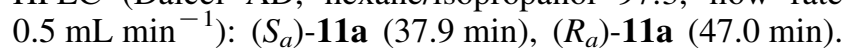
The crude reaction product showed $98 \%$ ee when compared against racemic material, (thiocarbonate $\left(S_{a}\right)$-10 giving $\left(S_{a}\right)$ 11a with retention of configuration). The retention times of the enantiomers were confirmed by the synthesis of the racemate. Formation $\left(S_{a}\right)$-11a was confirmed by comparison with an authentic sample of the $S_{a}$ enantiomer prepared by an alternative route. ${ }^{17}$

\section{9. $\left(S_{a}\right)$-2-(Pyrrolidine-1-carbothioyloxy)-2'-hydroxy- 1,1'-binaphthyl $\left(S_{a}\right)$-11b}

Prepared by an equivalent procedure to the synthesis of $\left(S_{a}\right)$ 11a from thiocarbonate $\left(S_{a}\right)$-10 $(50.0 \mathrm{mg}, 0.15 \mathrm{mmol})$ and pyrrolidine $(12.5 \mu \mathrm{L}, 0.15 \mathrm{mmol})$ in dichloromethane $(5 \mathrm{~mL})$ at room temperature $(2 \mathrm{~h})$. Recrystallisation from EtOH gave an off-white powder $41.9 \mathrm{mg}$ (70\%). Mp 276$278^{\circ} \mathrm{C} ;[\alpha]_{\mathrm{D}}=-307 \quad\left(c=0.1, \mathrm{CH}_{2} \mathrm{Cl}_{2}, 29^{\circ} \mathrm{C}\right) . \quad \mathrm{IR}(\mathrm{KBr}$ disc): $\nu_{\max } 3422 \mathrm{w}, 2923 \mathrm{w}, 1716 \mathrm{w}, 1523 \mathrm{w}, 1454 \mathrm{w}, 1275 \mathrm{~m}$, $1260 \mathrm{~m}(\mathrm{C}=\mathrm{S}), 764 \mathrm{~s}, 750 \mathrm{~s} \mathrm{~cm}^{-1}$; ${ }^{1} \mathrm{H} \mathrm{NMR}\left(\mathrm{CDCl}_{3}\right.$, $500.1 \mathrm{MHz}): \delta_{\mathrm{H}} 1.42-1.57\left(1 \mathrm{H}, \mathrm{m}, \mathrm{NCH}_{2 \alpha}\right) 1.71-1.79$ $\left(3 \mathrm{H}, \mathrm{m}, \mathrm{NCH}_{2 \alpha / \beta}\right), 2.56-2.63\left(1 \mathrm{H}, \mathrm{m}, \mathrm{NCH}_{2} \mathrm{CH}_{2 \alpha}\right), 3.23-$ $3.29\left(1 \mathrm{H}, \mathrm{m}, \mathrm{NCH}_{2} \mathrm{CH}_{2 \beta}\right), 3.5-3.59\left(2 \mathrm{H}, \mathrm{m}, \mathrm{NCH}_{2} \mathrm{CH}_{2 \alpha / \beta}\right)$, $5.89(1 \mathrm{H}, \mathrm{s}, \mathrm{OH}), 7.07\left(1 \mathrm{H}, \mathrm{d}, J=8.0 \mathrm{~Hz}, \mathrm{H}_{8}\right.$ or $\left.8^{\prime}\right), 7.23-$ $7.37(5 \mathrm{H}, \mathrm{m}, \mathrm{Ar}), 7.46\left(1 \mathrm{H}, \mathrm{d}, J=8.9 \mathrm{~Hz}, \mathrm{H}_{3}\right.$ or $\left.3^{\prime}\right), 7.50(1 \mathrm{H}$, broad apparent t, $J=7.2 \mathrm{~Hz}, \mathrm{H}_{6,6^{\prime}}$ or $\left.7,7^{\prime}\right), 7.48(1 \mathrm{H}, \mathrm{d}, J=$ $\left.8.0 \mathrm{~Hz}, \mathrm{H}_{5,5^{\prime}}\right), 7.88\left(1 \mathrm{H}, \mathrm{d}, J=8.9 \mathrm{~Hz}, \mathrm{H}_{4,4^{\prime}}\right) 7.97(1 \mathrm{H}, \mathrm{d}$, $\left.J=8.5 \mathrm{~Hz}, \mathrm{H}_{5,5^{\prime}}\right), 8.05\left(1 \mathrm{H}, \mathrm{d}, J=8.8 \mathrm{~Hz}, \mathrm{H}_{4}\right.$ or $\left.4^{\prime}\right) ;{ }^{13} \mathrm{C}$ $\operatorname{NMR}\left(\mathrm{CDCl}_{3}, 126.0 \mathrm{MHz}\right): \delta_{\mathrm{C}} 24.5,25.6,48.4,52.4,115.1$, $119.4,123.1,123.6,124.1,125.0,126.0,126.3,126.6$, 
$127.4,128.0,128.4,129.1,130.1,130.2,132.3,133.7$, 133.8, 151.3, 152.4, $184.3(\mathrm{C}=\mathrm{S}) ; \mathrm{m} / \mathrm{z}(\mathrm{EI}): 399\left(\mathrm{M}^{+}\right.$, 91\%), 284(78), 268 (41); 239(43\%); 114(100\%); 72(42\%); 55(32\%). [Found (EI, HRMS): $\mathrm{M}^{+} 399.1284 \mathrm{C}_{25} \mathrm{H}_{21} \mathrm{O}_{2} \mathrm{SN}$ requires 399.1293.]. Chiral HPLC under the conditions used for 11a led to the observation of only a single peak.

\subsection{Preparation of silica supported ligands 11c-d}

Pelleted 3a or $\mathbf{3} \mathbf{g}\left(0.15 \mathrm{~g}\right.$, loading $1.70 \mathrm{mmol} \mathrm{g}^{-1}$, $0.25 \mathrm{mmol} \mathrm{NHR} ; \mathrm{R}=\mathrm{H}, \mathrm{Me})$ in dichloromethane $(1.5 \mathrm{~mL})$ was treated with solid thiocarbonate $\left(S_{a}\right)$-10 (2 equiv $0.50 \mathrm{mmol}$ ) under an argon atmosphere and the reaction allowed to stir at room temperature $(2 \mathrm{~h})$. The weight of the crude pellets indicated a high coupling yield $(>90 \%)$. However, after extensive washing with dichloromethane and drying to constant weight much lower yields were attained. Yield for 11c: $183.1 \mathrm{mg}$ (indicating $0.54 \mathrm{mmol} \mathrm{g}^{-1}$, $40 \%$ ). Yield for 11d: $176.0 \mathrm{mg}$ (indicating $0.44 \mathrm{mmol} \mathrm{g}^{-1}$, $31 \%)$.

\section{Acknowledgements}

The European Union is thanked for its support through the DIAMeCTS Marie Curie Training Site (Contract HPMTCT-2001-00334) and project LIGBANK (Contract FP6505267-1). We are grateful to Dr Steve Hawker (JohnsonMatthey) and Mr Derek Atkinson (Grace Davison Europe) for generous gifts of mesoporous silica pellets and advice. We thank Drs. Robert Mokya, and Ed Lester for help with BET and TGA studies respectively.

\section{References and notes}

1. Overviews of solid-phase organic (and combinatorial) synthesis (a): Nicolaou, K. C., Hanko, R., Hartwig, W., Eds.; Handbook of Combinatorial Chemistry; Wiley-VCH: Weinheim, 2002; Vol. 1-2. (b) Zaragoza Dorwald, F. Organic Syntheses on Solid Phase; Wiley-VCH: Weinheim, 2000. (c) An extensive compilation of recent results is available at: www.combinatorial.com.

2. Overviews of polystyrene type supports: Haag, R., Hebel, A., Stumbé, J.-F., in Ref. 1a, p 46 and references therein.

3. Commercial silica supported products: Sigma-Aldrich list over 50 functionalised silica gels (scavengers, bases, and linkers) in their 2004 catalogue with loadings of $0.5-2.5 \mathrm{mmol} \mathrm{g}^{-1}$. Additionally, morpholine and related supported bases may be obtained from SiliCycle Inc (www.silicycle.com).

4. Silica-powder supported reagents: (a) Carpino, L. A.; Mansour, E. M. E.; Knapczyc, J. J. Org. Chem. 1983, 48, 666-669. (b) Thompsona, L. A.; Combsa, A. P.; Trainor, G. L.; Wangb, Q.; Langloisb, T. J.; Kirkland, J. Comb. Chem. High Through. Screen 2000, 3, 107-115. (c) Carpino, L. A.; Ismail, M.; Truran, G. A.; Mansour, E. M. E.; Iguchi, S.; Ionescu, D.;
ElFaham, A.; Riemer, C.; Warrass, R. J. Org. Chem. 1999, 64, 4324-4338.

5. Silica-powder supported catalysts: (a) Macquarrie, D. J. Chem. Commun. 1997, 601-602. (b) Macquarrie, D. J.; Clark, J. H.; Lambert, A.; Mdoe, J. E. G.; Priest, A. React. Funct. Polym. 1997, 35, 153-158. (c) Tundo, P.; Venturello, P. J. Am. Chem. Soc. 1979, 101, 6607-6613. (d) Kurusu, Y. Chin. J. Polym. Sci. 1999, 17, 1-12. (e) Price, P. M.; Clark, J. H.; Macquarrie, D. J. J. Chem. Soc. Dalton Trans. 2000, 101-110.

6. Solid-phase synthesis on silica powder: (a) Lee, J. W.; Louie, Y. Q.; Walsh, D. P.; Chang, Y-T. J. Comb. Chem. 2003, 5, 330-335. (b) Palmacci, E. R.; Hewitt, M. C.; Seeberger, P. H. Angew. Chem., Int. Ed. 2001, 40, 4433-4436. (c) Keana, J. F. W.; Shimizu, M.; Jernstedt, K. K. J. Org. Chem. 1986, 51, 1642-1644. (d) Sucholeiki, I.; Pavia, M. R.; Kresge, C. T.; McCullen, S. B.; Malek, A.; Schramn, S. Mol. Divers. 1998, 3, 161-171.

7. Glass bead references and related: (a) Haag, R.; Hebel, A.; Stumbé, J.-F. in Ref. 1a, p 46 and references therein. (b) Anson, M. S.; Leese, M. P.; Tonks, L.; Williams, J. M. J. J. Chem. Soc., Dalton Trans. 1998, 3529-3538.

8. Timofte, R. S.; Woodward, S. Tetrahedron Lett. 2004, 45, 39-42.

9. Hamaya, J.; Suzuchi, T.; Hoshi, T.; Shimizu, K.; Kitayama, Y.; Hagiwara, H. Synlett 2003, 873-875.

10. Activation of silica: Kurusu, Y. Chin. J. Polym. Sci. 1999, 17, $1-12$.

11. Hawker, S. Chemical Catalyst Development, Johnson Matthey Ltd. Personal communication.

12. Values determined through modelling on Spartan'02 from wavefun.com.

13. (a) Lippens, G.; Warrass, R.; Wieruszeski, J.-M.; RousselotPailley, P.; Chessari, G. Comb. Chem. High Through. Screen. 2001, 4, 333-351. (b) Keifer, P. A. Drug Discovery Today 1997, 2, 468-478.

14. Khitrin, A. K.; Fung, B. M.; McGeorge, G. In Encyclopedia of Nuclear Magnetic Resonance; Wiley: UK, 2002; Vol 9, pp 91-98 and references within.

15. Butler, I. R.; Cullen, W. R.; Han, N. F.; Herring, F. G.; Jagannathan, N. R.; Ni, J. Appl. Organomet. Chem. 1988, 2, 263-275.

16. (a) Lormann, M.; Dahmen, S.; Bräse, S. Tetrahedron Lett. 2000, 41, 3813-3816. (b) Lazny, R.; Sienkiewicz, M.; Bräse, S. Tetrahedron 2001, 57, 5825-5832.

17. (a) Bennett, S. M. W.; Brown, S. M.; Cunningham, A.; Dennis, M. R.; Muxworthy, J. P.; Oakley, M. A.; Woodward, S. Tetrahedron 2000, 56, 2847-2855. (b) Bennett, S. M. W.; Brown, S. M.; Muxworthy, J. P.; Woodward, S. Tetrahedron Lett. 1999, 40, 1767-1770. (c) Kodama, H.; Okazaki, A.; Segi, A.; Shimotsuki, A.; Ohta, T.; Furukawa, I. Sci. Eng. Rev. Doshisha Uni. 2000, 41, 26-32. (d) Kodama, H.; Okazaki, A.; Segi, A.; Shimotsuki, A.; Ohta, T.; Furukawa, I. Chem Abs. 2000, 133, 237651.

18. Yoder, C. M. S.; Zuckerman, J. J. J. Hetrocycl. Chem. 1967, 4, $166-167$.

19. Kolb, H. C.; Finn, M. G.; Sharpless, K. B. Angew. Chem., Int. Ed. 2001, 40, 2004-2021. 